\title{
Growth and yield estimation of Chamaecyparis spp. through tree ring analysis
}

\begin{abstract}
D. K. Kharal ${ }^{1}$ and T. Fujiwara ${ }^{2}$
Tree ring analysis is one of the most useful methods in volume and biomass estimation especially of the conifer trees. Ring width and ring density are important parameters in dendrochronological research. The present research was carried out with the aim of estimating the radial and volumetric growth of the Japanese Cypress trees (Chamaecyperis obstusa and C. pisifera). Destructive method was used while collecting the wood samples from the selected trees. Ring width and ring density were measured using soft X-ray densitometry method using micro-densitometer. Computer programme, developed by the Forestry and Forest Products Research Institute, Japan was used to analyze the ring with and ring density data. The average ring width of the Chamaecyparis spp. was found to be about $3.4 \mathrm{~mm}$ at the age of 30 years. However, two types of growth pattern were observed in the trees. Average radial growth was about $5 \%$ every year during the first 20 years of the tree age, whereas, the average radial growth was negative during the age of 20-30 years. Average density of the tree rings were increased by about $11 \%$ in each height of the trees starting from the ground. Similarly, the stem density decreased by about $3.4 \%$ annually along the radial direction from the pith.
\end{abstract}

Key words: Dendrochronology, ring width, ring density, tree biomass, soft X-ray densitometry

$\mathrm{D}$ endrochronology, study of tree rings, has extensive applications now-a-days. The different disciplines such as archaeology and history, climatology, forest ecology, landscape management, geomorphology, glaciology, hydrology, environmental science, wood anatomy and physiology are applied dendrochronology as an analytical tool (Braker, 2002). The systematic studies of tree rings started before the turn off 1900s especially from Western North America, Eastern North America, Western and Eastern Europe. The early works on tree ring analysis in the North America were primarily focused to find the relationship between precipitation and tree growth (Robinson, 1992 and Cook, 1992). On the other hand, the early period of tree ring analysis in Western Europe has been used mostly to study the impact of industrial pollution on the environment and a large number of such studies have demonstrated a correlation between air pollution and growth increment (Eckstein and Pilcher, 1992). Similarly, the first notable tree ring works in East Europe particularly in the former USSR was carried out to identify the relationship between width of annual ring and annual

precipitation and narrowest rings were found during dry years (Kairiukstis and Shiyatov, 1992). Tree ring research started relatively late in some countries of the Southern Hemisphere namely the South America, South Africa, Australia and New Zealand.

Tree ring analysis is one of the most useful methods for forest resources assessment because it gives information on annual growth of the trees. Tree ring analysis provides more precise information on the different dimensions of forest ecology and management such as choices of forest species composition, changes in environmental conditions, investigation of age effects, cost efficient forest management, site selection for afforestation and reforestation which contribute in achieving the sustainability from technical, environmental and economic perspective (Spiecker, 2002). Whereas there are several types of methods for tree ring analysis, soft X-ray densitometry has an advantage that it can obtain not only tree ring width but also density of woods. The ring width shows annual growth and volumetric growth. When density of wood is available, weight of

\footnotetext{
${ }^{1}$ Department of Forest Research and Survey, Kathmandu, Nepal.

E-mail:deepak_kharal@yahoo.com

${ }^{2}$ Department of Wood Properties, Forestry and Forest Products Research Institute, Ibaraki, Japan. 
trunk can be calculated from multiplication of the volume and density. Amount of carbon in a tree stem is an important parameter for the assessment of forest on the carbon absorption. The primary interest of this study is to estimate the radial as well as volumetric growth of Japanese cypress trees using soft X-ray densitometry analysis. It further assesses the stem density of the trees using the same method.

\section{Materials and methods}

\section{Study area}

Sampled trees were selected from the strip plantation of the Institute of Forestry and Forest Products Research Institute (FFPRI) area adjacent to the Tsukuba Science City in Ibaraki prefecture of Japan. The strip plantation is found as the mixed stand both in terms of species composition and stem size. Both the Japanese Cypress trees (Chamaecyperis obstusa and C. pisifera) dominate the plantation. Cryptomeria japonica is also found in small number.

Growth in diameter, volume and biomass of the tree stem are directly and closely correlated with weather and climate situation of the area. Five years weather data (2002-2006) of the study area were used to understand the local climate for this research purpose. The temperature reached up to $37^{\circ} \mathrm{C}$ in July 2004 whereas minimum temperature $\left(-8.6^{\circ} \mathrm{C}\right)$ was recorded in January 2003 (http://www.jma.go.jp/jma/index.html, 2008). Regarding precipitation, $1616.5 \mathrm{~mm}$ of annual rainfall was recorded during the year 2006 with $592 \mathrm{~mm}$ in October 2004 as maximum and $1 \mathrm{~mm}$ in December 2005 as minimum. Monthly average humidity of the area was about $74 \%$ ranging from $57 \%$ in January 2002 to $88 \%$ in July 2006. Wind velocity was one of the important parameters of weather situation which was about $2.45 \mathrm{~m} / \mathrm{sec}$ in terms of annual average varying from $1.8 \mathrm{~m} / \mathrm{sec}$ in November 2004 and $3 \mathrm{~m} / \mathrm{sec}$ in April 2002. The maximum wind velocity was recorded in $16 \mathrm{~m} / \mathrm{sec}$ in October 2002. The area had around 1960 sunshine hours in annual basis having maximum sunshine hours (250 hours) in July 2004. Interestingly, the minimum sunshine hours (56 hours) was noticed in the same month in 2003. The annual average solar radiation of the area was about $13.18 \mathrm{MJ} / \mathrm{m}^{2}$ ranging from $7 \mathrm{MJ} / \mathrm{m}^{2}$ in November 2003 to $22.1 \mathrm{MJ} / \mathrm{m}^{2}$ in July 2004 .

\section{Sample collection}

Medium sized trees of the Japanese Cypress, $C$. obstusa and C. pisifera, were considered in this research. Trees from the plantation were selected from different length of the strip. The diameter was measured at $1.3 \mathrm{~m}$ from the ground level. The trees were harvested at $20 \mathrm{~cm}$ height from the ground. The harvested trees were logged into pieces each one having one meter in length up to tip of the trees. Each ring having 10 centimeter in width was collected from bottom of each $\log$ as the sample which was further processed in the saw milling to prepare one centimeter-wide wood strip having $2 \mathrm{~mm}$ in thickness. Knots and damaged parts were avoided while preparing the wood strip for ring analysis. Length of the strips were measured from simple measuring scale before keeping in the oven dryer at $65 \%$ relative humidity and $20^{\circ} \mathrm{C}$ temperature to maintain about $10-11 \%$ moisture content in all diameters range so that comparison of the different rings in terms of width and density can be made standard.

The wood density was measured through volumetric-gravimetric methods and gravimetric methods. Volumetric-gravimetric method was used when wood samples were large whereas gravimetric method was used to identify the density variation within annual rings. Out of the various methods, Photometry, Morphometry, Radiometry and X-ray densitometry (Schweingruber, 1992) used in tree ring analysis, soft X-ray densitometry analysis was used for this research. X- Ray films of the treated wood strips were taken using 20 $\mathrm{kVp}$ pressure in 14 milli Ampere up to 4 minute. Microdensitometer was used to measure the ring width and ring density through $\mathrm{X}$-ray film reading.

\section{Data analysis}

There are several microcomputer systems commonly used in the analysis of tree ring density some of which are CompU-TA, TRIMS, Belfast Tree -Ring Programs, CATRAS etc. In the present study, programme developed by the Wood Anatomy Laboratory of the Forestry and Forest Products Research Institute, Tsukuba Science City, Japan was used to analyze the ring width and ring density. False rings were identified and adjusted during the analysis. Data on ring width, average ring density, maximum ring density, minimum ring density, range of density within the ring, percentage of late wood and early wood within the 
ring, percentage of late wood and early wood over density of $550 \mathrm{~kg} / \mathrm{cum}$ were identified as shown in the output of the computer programme. The total sum of the area of the annual ring was multiplied with stem length to derive stem volume of each log. Stem biomass was derived using average ring density and stem volume.

\section{Results and discussion}

The general observations of the sampled and surrounding trees are depicted in table 1. The sampled trees were surrounded by a group of trees in the strip plantation. Four to six numbers of surrounding trees within the total distance ranging from $14.5 \mathrm{~m}$ to $26.3 \mathrm{~m}$ having total sum of diameter within the limit of $126.5 \mathrm{~m}$ to $200.5 \mathrm{~m}$ were recorded before harvesting the sampled trees. This provides important information while analyzing the tree rings since tree growth is directly affected by root and crown space.

\section{Ring width analysis}

Ring width varies from species to species and even tree to tree within the same species of same localities. Some trees also have different ring structure in different stem height. Table 2 shows the average radial increment of the tree in terms of ring width in different height class. The average diameter increment was found to be decreased gradually from base to the top in all trees. The sum of all ring width corresponded to the total diameter of the trees without bark as shown in the same table.

Table 1: General obserrvation of the sampled trees

\begin{tabular}{lcccc}
\hline & & \multicolumn{3}{c}{$\begin{array}{l}\text { Observation of the surrounding trees within the limit of 10 m } \\
\text { radius from the sampled tree }\end{array}$} \\
\cline { 2 - 5 } Latin name & $\begin{array}{c}\text { Tree } \\
\text { Symbol }\end{array}$ & $\begin{array}{l}\text { Total number } \\
\text { of surrounding } \\
\text { trees }\end{array}$ & $\begin{array}{c}\text { Sum of dia. of(m) } \\
\text { surrounding trees } \\
\text { (cm) }\end{array}$ & $\begin{array}{c}\text { Sum of distance of } \\
\text { surrounding trees } \\
\text { (m) }\end{array}$ \\
\hline $\begin{array}{l}\text { Chamaecyparis obstusa } \\
\text { Chamaecyparis obstusa }\end{array}$ & H1 & 4 & 126.5 & 14.5 \\
Chamaecyparis obstusa & H3 & 6 & 200.5 & 22.2 \\
Chamaecyparis pispfera & S1 & 6 & 183.5 & 26.3 \\
\hline
\end{tabular}

Table 2 : Ring width analysis by stem height

\begin{tabular}{|c|c|c|c|c|c|c|c|c|}
\hline \multirow{2}{*}{$\begin{array}{c}\text { Tree } \\
\text { Height } \\
\text { (m) }\end{array}$} & \multicolumn{2}{|c|}{ H1 } & \multicolumn{2}{|c|}{ H2 } & \multicolumn{2}{|c|}{ H3 } & \multicolumn{2}{|c|}{ S1 } \\
\hline & $\begin{array}{c}\text { Av. } \\
\text { ring } \\
\text { width }\end{array}$ & $\begin{array}{l}\text { Sum of } \\
\text { width }\end{array}$ & $\begin{array}{c}\text { Av. } \\
\text { ring } \\
\text { width }\end{array}$ & $\begin{array}{c}\text { Sum of } \\
\text { width }\end{array}$ & $\begin{array}{c}\text { Av. } \\
\text { ring } \\
\text { width }\end{array}$ & $\begin{array}{l}\text { Sum of } \\
\text { width }\end{array}$ & $\begin{array}{c}\text { Av. } \\
\text { ring } \\
\text { width }\end{array}$ & $\begin{array}{c}\text { Sum of } \\
\text { width }\end{array}$ \\
\hline & $\mathbf{m m}$ & $\mathbf{c m}$ & $\mathbf{m m}$ & $\mathbf{c m}$ & $\mathbf{m m}$ & cm & $\mathbf{m m}$ & $\mathbf{c m}$ \\
\hline 0.2 & 3.48 & 20.90 & 4.59 & 27.57 & 3.43 & 20.60 & 4.53 & 22.64 \\
\hline 1.2 & 3.39 & 16.28 & 3.55 & 18.44 & 3.05 & 15.87 & 4.13 & 18.16 \\
\hline 2.2 & 3.59 & 15.08 & 4.01 & 17.65 & 3.28 & 14.42 & 4.32 & 17.29 \\
\hline 3.2 & 3.27 & 13.10 & 4.09 & 15.56 & 3.18 & 12.70 & 3.72 & 14.12 \\
\hline 4.2 & 3.28 & 11.81 & 3.88 & 13.18 & 2.93 & 9.95 & 3.64 & 12.36 \\
\hline 5.2 & 3.27 & 10.48 & 3.81 & 11.44 & 2.74 & 8.22 & 3.29 & 9.86 \\
\hline 6.2 & 2.79 & 8.36 & 3.51 & 9.82 & 2.24 & 5.84 & 2.99 & 7.77 \\
\hline 7.2 & 2.39 & 5.73 & 3.44 & 8.25 & 1.76 & 3.16 & 1.91 & 3.83 \\
\hline 8.2 & 1.71 & 3.08 & 3.27 & 6.54 & 2.00 & 0.80 & 1.63 & 1.95 \\
\hline 9.2 & & & 2.62 & 4.20 & & & & \\
\hline Average & 3.18 & 11.65 & 3.83 & 13.26 & 2.97 & 10.17 & 3.67 & 12.00 \\
\hline
\end{tabular}


The growth parameters i.e., ring width, percentage of early wood and late wood widths as well as ring density are the primary focus of measurement in the field of forest ecology and management (Braker, 2002). The width of the annual rings and tree growth are mostly determined by the climatic and other abiotic factors such as light, temperature, precipitation, wind, nutrient, root and crown space, mechanical damages, air and soil pollution whereas genetics control the growth to some extend (Schweingruber, 1996). Schweingruber (1989) has noticed wider rings of Poplar trees as compared to the Bilberry trees growing in the same climatic condition. The reason for decreasing ring width can be explained through ecological perspective. As mentioned above, the sampled trees were medium in size and dominated by a group of large sized trees with big crown. Ring width may be started to decrease once the sampled trees reached up to the crown base of the dominated trees in the strip plantation.

All trees have higher growth rate in their early age and continuously decrease until the harvesting time. The result showed that $C$. obstusa increased by about $3.33 \mathrm{~mm}$ per annum in its radial direction which varied from $4.59 \mathrm{~mm}$ in maximum to $1.71 \mathrm{~mm}$ in minimum level. Similarly, the rate of growth of $C$. pisifera was little higher than that of the C. obstusa which was about $3.67 \mathrm{~mm}$ per annum ranging from $4.53 \mathrm{~mm}$ in maximum and $1.63 \mathrm{~mm}$ in minimum level. The analysis further showed that even three trees of $C$. obstusa species of the same locality had different ring structure in the same height class. Various climatic and non climatic factors affect in the vegetation growth out of which temperature and precipitation have strong influence in the growth pattern (Fritts, 1976; Kozlowsky and Pallardy 1997, Leal et al., 2007). However, ecological dimensions are equally important to understand the growth pattern of the trees. In the present study, the sampled trees were found influenced by the locality, crown coverage and stem density of the stand. It can be explained by the observation as shown in table 1 . The number of rings by height class of each sampled trees for the given year is presented in table 3 .

The total number of annual ring in all trees of C. obstusa species were 30 in the ground level but their number was different in different height class. This particularly showed the age of the trees by height class. C. pisifera had 25 annual rings by the end of harvesting time. Table 3 shows that it required at least 21 years to reach the height of $8.2 \mathrm{~m}$ from the ground for $\mathrm{H} 1$, whereas 28 years was needed to reach the same height for the $\mathrm{H} 3$. The gap of the rings within each height class showed that early and late growth in terms of height was small compared to middle age in all trees of both species. The early and late stages of all trees had smaller ring width compared to the middle stage. The trees grew little faster during 1977 to 1987 period and started to decline until the harvesting time (Fig. 1).

\section{Ring density analysis}

The density varies not only from species to species but also from bottom to top and pith to bark of the same tree. The average density of the trees by stem height is presented in table 4 . The average

Table 3: Number of rings by height class of sampled trees

\begin{tabular}{ccccc}
\hline $\begin{array}{c}\text { Height class } \\
(\mathbf{m})\end{array}$ & \multicolumn{4}{c}{ Number of tree rings } \\
\cline { 2 - 5 } & H1 & H2 & H3 & S1 \\
\hline 0.2 & 30 & 30 & 30 & 25 \\
1.2 & 24 & 26 & 26 & 22 \\
2.2 & 21 & 22 & 22 & 20 \\
3.2 & 20 & 19 & 20 & 19 \\
4.2 & 18 & 17 & 17 & 17 \\
5.2 & 16 & 15 & 15 & 15 \\
6.2 & 15 & 14 & 13 & 13 \\
7.2 & 12 & 12 & 9 & 10 \\
8.2 & 9 & 10 & 2 & 6 \\
9.2 & & 8 & & \\
\hline
\end{tabular}




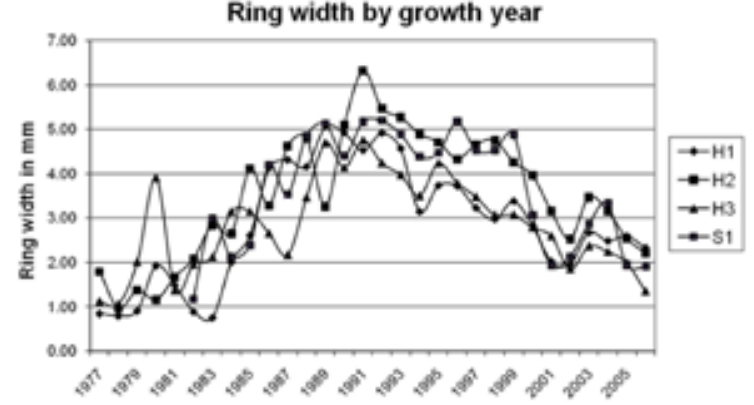

Fig. 1: Ring width by growth year

density increased with the increase in height. The opposite is true in case of diameter that is biomass density in centre of the tree, which is called pith, was higher compared to the outer circle as shown in figure 2 . The average density of the C. obstusa was around $518 \mathrm{~kg} / \mathrm{cum}$, little higher than the C. pisifera. Such figures are different than the basic density because ring density was measured at around $11 \%$ moisture content.

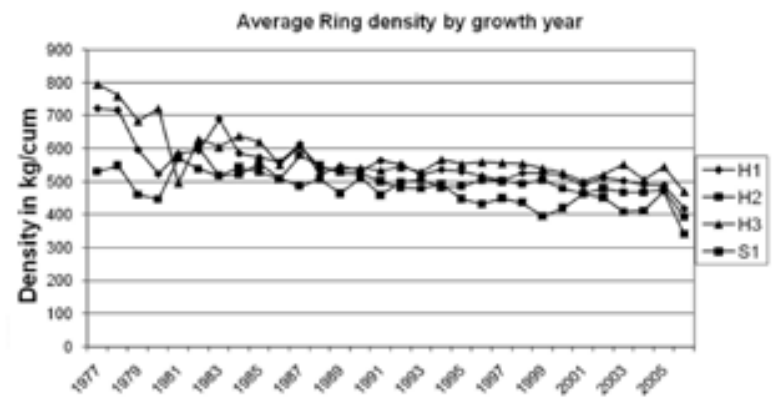

Fig. 2: Ring density in radial direction of the stem
Table 4: Stem density $\left(\mathrm{kg} / \mathrm{m}^{3}\right)$ by height of tree

\begin{tabular}{ccccc}
\hline \multirow{2}{*}{$\begin{array}{c}\text { Stem } \\
\text { height } \\
(\mathbf{m})\end{array}$} & \multicolumn{4}{c}{ Tree Symbol } \\
\cline { 2 - 5 } & H1 & H2 & H3 & S1 \\
\hline 0.2 & 518 & 432 & 565 & 432 \\
1.2 & 529 & 495 & 526 & 466 \\
2.2 & 484 & 474 & 491 & 460 \\
3.2 & 508 & 442 & 553 & 405 \\
4.2 & 528 & 473 & 540 & 414 \\
5.2 & 527 & 504 & 547 & 470 \\
6.2 & 538 & 520 & 566 & 474 \\
7.2 & 545 & 521 & 630 & 499 \\
8.2 & 583 & 541 & 657 & 617 \\
9.2 & & 585 & & \\
\hline Average & $\mathbf{5 2 3}$ & $\mathbf{4 8 5}$ & $\mathbf{5 4 7}$ & $\mathbf{4 5 5}$ \\
\hline
\end{tabular}

\section{Analysis of stem volume}

Average volume of each ring in each height of the trees continuously decreased from bottom to the top of all trees. An average ring of each height of the C. obstusa tree had $0.58-1.02 \mathrm{~cm}^{3}$ wood volume producing about $3.18 \mathrm{cft}$ of wood volume in $\mathrm{H} 3$ to $6.2 \mathrm{cft}$ in $\mathrm{H} 2$. Table 5 shows the average and sum of volume of rings by each height class of the trees.

Table 5: Average and sum of volume of rings by height class

\begin{tabular}{ccccccccc}
\hline $\begin{array}{c}\text { Stem } \\
\text { height } \\
(\mathbf{m})\end{array}$ & \multicolumn{3}{c}{$\begin{array}{c}\text { Average volume of each ring in all years } \\
\text { by height }\end{array}$} & $\left.\mathbf{H} \mathbf{c m}^{\mathbf{3}}\right)$ & \multicolumn{3}{c}{$\begin{array}{c}\text { Sum of volume of all rings in all years } \\
\text { by height (cft) }\end{array}$} \\
\cline { 2 - 9 } & $\mathbf{H 2}$ & $\mathbf{H 3}$ & $\mathbf{S 1}$ & $\mathbf{H 1}$ & $\mathbf{H 2}$ & $\mathbf{H 3}$ & $\mathbf{S 1}$ \\
\hline 0.2 & 1.07 & 1.84 & 1.02 & 1.59 & 1.14 & 1.95 & 1.08 & 1.41 \\
1.2 & 0.91 & 1.12 & 0.69 & 1.31 & 0.77 & 1.03 & 0.63 & 1.02 \\
2.2 & 0.79 & 1.18 & 0.63 & 1.28 & 0.59 & 0.92 & 0.49 & 0.90 \\
3.2 & 0.64 & 0.98 & 0.60 & 0.67 & 0.45 & 0.65 & 0.42 & 0.45 \\
4.2 & 0.60 & 0.86 & 0.43 & 0.63 & 0.38 & 0.52 & 0.26 & 0.38 \\
5.2 & 0.51 & 0.77 & 0.33 & 0.51 & 0.29 & 0.41 & 0.18 & 0.27 \\
6.2 & 0.36 & 0.62 & 0.20 & 0.37 & 0.19 & 0.30 & 0.09 & 0.17 \\
7.2 & 0.22 & 0.51 & 0.10 & 0.13 & 0.09 & 0.22 & 0.03 & 0.04 \\
8.2 & 0.09 & 0.40 & 0.03 & 0.07 & 0.03 & 0.14 & 0.00 & 0.01 \\
9.2 & 0.00 & 0.22 & 0.00 & 0.00 & 0.00 & 0.06 & 0.00 & 0.00 \\
\hline Ave/sum & $\mathbf{0 . 6 7}$ & $\mathbf{1 . 0 2}$ & $\mathbf{0 . 5 8}$ & $\mathbf{0 . 9 0}$ & $\mathbf{3 . 9 3}$ & $\mathbf{6 . 2 0}$ & $\mathbf{3 . 1 8}$ & $\mathbf{4 . 6 5}$ \\
\hline
\end{tabular}




\section{Biomass analysis}

Biomass assessment is one of the important components of tree ring analysis. Here, biomass was measured in terms of weight. Table 6 depicts
Per Annum biomass increment varied from $1.6 \mathrm{kgs}$ in $\mathrm{H} 3$ to $2.5 \mathrm{kgs}$ in $\mathrm{H} 2$ whereas increment of S1 was about $2.2 \mathrm{kgs}$ per annum in the same locality.

Table 6: Average and sum of weight of all rings of all years by height class

\begin{tabular}{|c|c|c|c|c|c|c|c|c|}
\hline \multirow{2}{*}{$\begin{array}{l}\text { Stem } \\
\text { height } \\
\text { (m) }\end{array}$} & \multicolumn{4}{|c|}{$\begin{array}{l}\text { Average wt of each ring in all years by } \\
\text { height }(\mathrm{g})\end{array}$} & \multicolumn{4}{|c|}{$\begin{array}{c}\text { Sum of wt of all rings in all years by } \\
\text { height ( } \mathrm{kg})\end{array}$} \\
\hline & H1 & H2 & H3 & S1 & H1 & H2 & H3 & S1 \\
\hline 0.2 & 556.1 & 796.2 & 575.0 & 689.1 & 16.7 & 23.9 & 17.3 & 17.2 \\
\hline 1.2 & 473.8 & 482.6 & 390.5 & 568.2 & 11.4 & 12.5 & 10.2 & 12.5 \\
\hline 2.2 & 410.7 & 509.9 & 353.9 & 552.6 & 8.6 & 11.2 & 7.8 & 11.1 \\
\hline 3.2 & 330.3 & 421.8 & 337.1 & 288.5 & 6.6 & 8.0 & 6.7 & 5.5 \\
\hline 4.2 & 308.8 & 371.4 & 244.0 & 272.4 & 5.6 & 6.3 & 4.1 & 4.6 \\
\hline 5.2 & 264.6 & 334.3 & 188.9 & 219.4 & 4.2 & 5.0 & 2.8 & 3.3 \\
\hline 6.2 & 188.8 & 266.5 & 110.8 & 161.8 & 2.8 & 3.7 & 1.4 & 2.1 \\
\hline 7.2 & 112.9 & 221.5 & 54.6 & 54.1 & 1.4 & 2.7 & 0.5 & 0.5 \\
\hline 8.2 & 45.5 & 172.5 & 16.7 & 29.3 & 0.4 & 1.7 & 0.0 & 0.2 \\
\hline 9.2 & & 95.9 & & & & 0.8 & & \\
\hline Ave/sum & 349.5 & 438.6 & 330.4 & 387.8 & 57.7 & 75.9 & 50.9 & 57.0 \\
\hline
\end{tabular}

the average weight of each ring grown in all years by height class. Average biomass of each ring in each height of the tree also continuously decreased from bottom to top of the trees. Average biomass in each ring in each height of the tree in $\mathrm{H} 1, \mathrm{H} 2$, $\mathrm{H} 3$ and $\mathrm{S} 1$ trees were about 350, 439, 330 and 387 grams equivalent to about 58,76, 60 and 57 kilograms of wood biomass in the respective trees.

Figure 3 for stem biomass of all trees corresponded to the $11 \%$ moisture content. A comparative figure for stem biomass in different moisture content is also presented in table 7 .

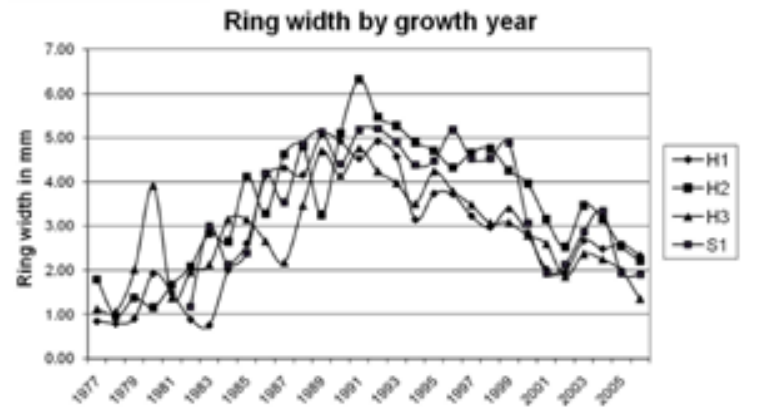

Fig. 3: Average ring biomass in all height by year
Table 7: Comparison of stem biomass by moisture content level

\begin{tabular}{lccc}
\hline \multirow{2}{*}{ Description } & \multicolumn{3}{c}{ Tree Symbol } \\
\cline { 2 - 4 } & H1 & H2 & S1 \\
\hline $\begin{array}{l}\text { Total green weight } \\
\text { of stem (kg) }\end{array}$ & 97.0 & 129.6 & 101.9 \\
$\begin{array}{l}\text { Total dry weight at } \\
11 \% \text { MC (kg) }\end{array}$ & 57.7 & 75.9 & 57.0 \\
$\begin{array}{l}\text { Total dry weight at } \\
0 \% \text { MC (kg) }\end{array}$ & 53.8 & 72.0 & 46.9 \\
\hline
\end{tabular}

The stem biomass increased by about 3.4\% annually at the age of 30 years. However, the rate of biomass growth during the first 20 years of tree age was about $5.6 \%$ annually. Figure 4 shows the sum of ring biomass in all height by year.

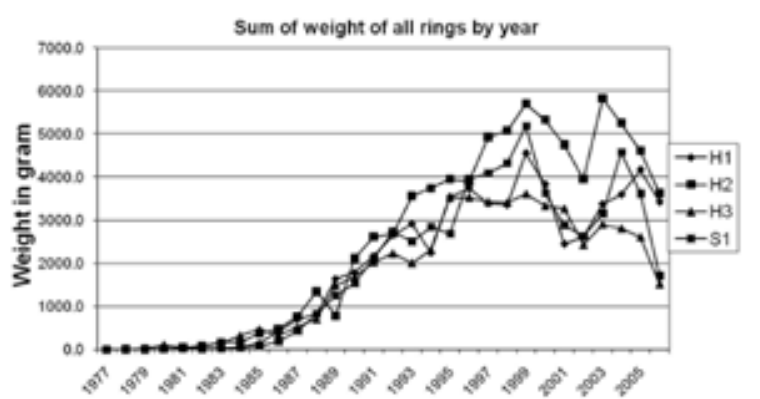

Fig. 4: Sum of ring biomass in all height by year 
Contrast to this, the biomass growth rate during the last 10 years of the tree age (20-30 years) was negative and equal about $10 \%$ per year. The reasons behind significant decrease of the biomass growth during the age of 20-30 years of the tree could be the competition with the surrounding trees for light, moisture and growing space.

\section{Acknowledgements}

We sincerely thank JICA Nepal to provide financial support to conduct this research at the Forestry and Forest Products Research Institute, Ibaraki, Japan. We further would like to thank Ms. Kana Yamashita to support in our lab work at the Institute.

\section{References}

Braker, O.U. 2002. Measuring and data processing in tree-ring research - a methodological introduction. Dendrochronologia 20/1-2: 203-216.

Cook,E. 1992. Dendrochronology inEastern North America. In Methods of Dendrochronology (eds.) Cook, E.R. and Kairiukstis, L. A. Kluwer Academic Publishers. Dordrecht, Holland.

Eckstein, D. and Pilcher, J. R. 1992. Dendrochronology in western Europe. In Methods of Dendrochronology (eds.) Cook, E.R. and Kairiukstis, L. A. Kluwer Academic Publishers. Dordrecht, Holland.

Fritts, H. C. 1976. Tree Rings and Climate. Academic Press, London, UK.

http://www.jma.go.jp/jma/index.html, cited in April, 2008.

Kairiukstis, L. and Shiyatov, S. 1992. Dendrochronology in the USSR. In In Methods of Dendrochronology (eds.) Cook, E.R. and Kairiukstis, L. A. Kluwer Academic Publishers. Dordrecht, Holland.
Kozlowsky, T. T. and Pallardy, S. G. 1997. Growth Control in Woody Plants. Academic Press, San Diego.

Leal, S., Melvin, T. M., Grabner, M., Wimmer, R. and Briffa, K. R. 2007. Tree ring-growth variability in the Austrian Alps: the influence of site, altitude, tree species and climate. Boreas 36: 426-440.

Robinson, W. J. 1992. Dendrochronology in Western North America: The Early Years. In Methods of Dendrochronology (eds.) Cook, E.R. and Kairiukstis, L. A. Kluwer Academic Publishers. Dordrecht, Holland.

Schweingruber, F. H., 1992. Radiodensitometry. In Methods of Dendrochronology (eds.) Cook, E.R. and Kairiukstis, L. A. Kluwer Academic Publishers. Dordrecht, Holland.

Schweingruber, F. H. 1996. Tree Rings and Environment Dendroecology. Birmensdorf, Swiss Federal Institute for Forest, Snow and Landscape Research. Berne, Stuttgart, Vienna, Haupt.

Schweingruber, F. H. 1989. Tree Rings: Basics and Applications of Dendrochronology. Kluwer Academic Publishers. Dordrecht, Holland.

Spiecker, H. 2002. Tree rings and forest management in Europe. Dendrochronologia 20/1-2: 203-216. 